\title{
PENGEMBANGAN PERANGKAT PEMBELAJARAN BERBASIS INKUIRI DENGAN MODEL LEARNING CYCLE 7E UNTUK MENINGKATKAN HASIL BELAJAR FISIKA TOPIK CAHAYA
}

\author{
Ida Fitriyah \\ Program Studi pendidikan Sains Program Pascasarjana Universitas Negeri Surabaya
}

\begin{abstract}
Abstrak: Penelitian ini merupakan penelitian pengembangan yang bertujuan mengembangkan perangkat pembelajaran berbasis inkuiri dengan model learning cycle 7E topik Cahaya, meliputi Silabus, RPP, Materi ajar, LKS dan Lembar Penilaian. Penelitian ini dilaksanakan di SMPN 1 Tuban melalui tiga tahap, yaitu pengembangan perangkat dengan model Kemp, validasi perangkat, dan ujicoba lapangan dengan rancangan one group pretest-posttest. Hasil dari penelitian ini adalah 1) Perangkat Pembelajaran berbasis inkuiri dengan model Learning Cycle $7 E$ valid untuk digunakan dalam pembelajaran; a) Hasil validasi perangkat menunjukkan perangkat pembelajaran yang dikembangkan berkategori baik dan dapat diterapkan dalam kegiatan belajar mengajar; b) Tingkat kesulitan perangkat yang dikembangkan rendah dan mudah dipahami siswa; c) Keterbacaan perangkat tinggi dan materi mudah dipahami; 2) Perangkat pembelajaran efektif digunakan dalam proses pembelajaran; a) Hasil belajar kognitif produk, proses, psikomotor, dan afektif menunjukkan peningkatan dengan kategori tinggi; b) Siswa memberikan respon positif terhadap perangkat pembelajaran yang dikembangkan. 3) Perangkat pembelajaran yang dikembangkan praktis digunakan dalam pembelajaran; a) keterlaksanaan RPP dalam kategori baik; b) Aktivitas siswa yang memiliki persentase tiga terbesar adalah menganalisis hasil percobaan, melakukan percobaan/ pengamatan, dan diskusi/tanya jawab. Penelitian ini berkesimpulan bahwa Perangkat Pembelajaran berbasis inkuiri dengan model Learning Cycle 7E topik Cahaya yang telah dikembangkan memenuhi unsur kevalidan, keefektifan dan kepraktisan, sehingga layak diimplementasikan dalam pembelajaran.
\end{abstract}

Kata-kata Kunci: Hasil belajar, model learning cycle 7E, pembelajaran berbasis inkuiri.

\begin{abstract}
This is the research of development that intends to develop learning purchase based on inquiry by $7 E$ learning cycle model in the light topic included syllabus, lesson plan, students book, students worksheet, and assesment sheet. This research is done by using three steps, they are Development of learning instrument with Kemp model, validation of instrument and field experiment by one group pretest-posttest design, which is done in SMPN 1 Tuban. The result of this research is 1) Learning instrument based on inquiry by $7 E$ learning cycle models is valid for being done in learning: a) The result of instrumen validity refers to learning instrument in good category and it can be used in teaching learning process ; b) The difficulty level of instrument is low a nd easy is understood by student; c) Readablety of instrumen is high and the materials easy is understood by students; 2) The learning instument is effective to use in learning process; a) the value of cognitive test, performence test and affective test refer to the improvement with high category; b) The students give a positive response to the learning process; 3) The learning instrument which has been developed is practical to use in learning process; a) The lesson plan that used is in a good category; b) the higest procentage of three student activity are analysis the result of experiment, doing experiment / observation, and discussion/question - answer. The conclusion of the research analising is the learning purchase which has been developed based on inquiry by $7 E$ learning cycle model in the light topic have fullfiled validity, effectify and practical to use, so itis proper to use in learning process.
\end{abstract}

Keywords: learning cycle $7 E$ model, learning achievement, learning based inquiry.

\section{PENDAHULUAN}

Hasil belajar yang diharapkan pada setiap proses pembelajaran adalah adanya peningkatan kompetensi yang dimiliki oleh peserta didik sedemikian rupa sehingga peserta didik dikatakan dapat mencapai ketuntasan dalam belajar. Ketuntasan Belajar dapat diperoleh apabila peserta didik mampu mencapai KKM yang ditetapkan oleh sekolah pada tiap bidang studi. Peningkatan hasil belajar, pelaksanaan proses pembelajaran yang efektif sesuai dengan apa yang telah dicanangkan pemerintah dalam
Standar Nasional Pendidikan adalah menjadi harapan semua lembaga pendidikan pada setiap proses pembelajaran.

Kenyataan di lapangan masih ditemukan berbagai kendala dalam pembelajaran IPA. Hasil observasi lapangan yang dilakukan peneliti di SMPN 1 Tuban, menunjukkan bahwa hasil belajar IPA, khususnya fisika masih rendah. Hasil wawancara dengan guru fisika di beberapa sekolah juga menyatakan bahwa salah satu kendala yang menyebabkan rendahnya hasil belajar siswa 
adalah rendahnya keaktifan siswa ketika proses pembelajaran, mereka cenderung pasif dan pembelajaran hanya terjadi satu arah (teacher-centered learning).

Permasalahan yang muncul adalah bagaimana model pembelajaran yang efektif dapat meningkatkan hasil belajar siswa, khususnya pada topik Cahaya. Untuk mewujudkan hal tersebut, peneliti merasa perlu mengembangkan model pembelajaran yang mungkin cocok untuk diterapkan pada topik cahaya, yaitu pembelajaran berbasis inkuiri dengan model Learning Cycle 7E karena model Learning Cycle 7E merupakan aplikasi model pembelajaran konstruktivis yang berpusat pada siswa (student centered) dan selalu melibatkan siswa secara langsung pada tiap fasenya sehingga siswa dapat menerapkan dan mengingat apa yang telah dipelajarinya secara lebih baik. Jika model ini diterapkan secara benar dan efektif maka hasil belajar siswa diharapkan akan meningkat.

Learning cycle 7E adalah model pembelajaran yang telah dikembangkan oleh Eisenkraft (2003) yang terdiri atas tujuh tahapan belajar yaitu: elicit (mendatangkan pengetahuan awal siswa), engage (membangkitkan minat), explore (mengeksplor), explain (menjelaskan), elaborate (menerapkan), evaluate (mengevaluasi), dan extend (memperluas). Ketujuh tahapan learning cycle 7E meliputi: 1) Elicit (mendatangkan pengetahuan awal siswa), yaitu fase untuk mengetahui sampai dimana pengetahuan awal siswa yang berhubungan dengan materi yang akan dipelajari (Eisenkraft, 2003); 2) Engage (membangkitkan minat), pada tahap ini guru berusaha membangkitkan minat siswa tentang topik yang akan diajarkan (Wena, 2009); 3) Explore (mengeksplor), pada tahap ini dibentuk kelompok-kelompok kecil, kemudian diberi kesempatan untuk bekerja sama dalam kelompok kecil tanpa pembelajaran langsung dari guru. Siswa didorong untuk bekerja sama dalam kelompok untuk menguji hipotesis dan atau membuat hipotesis baru, mencoba alternatif pemecahannya dengan teman sekelompok, melakukan dan mencatat pengamatan serta ide-ide atau pendapat yang berkembang dalam diskusi. Guru berperan sebagai fasilitator dan motivator (Wena, 2009); 4) Explain (menjelaskan), pada tahap ini guru membimbing siswa untuk menjelaskan hasil eksplorasi mereka (Eisenkraft, 2003). 5) Elaborate (menerapkan), tahap ini memberikan kesempatan bagi siswa untuk menerapkan pengetahuan mereka (Eisenkraft, 2003). 6) Extend (memperluas), pada fase extend pengetahuan diterapkan dalam konteks yang baru dan tidak terbatas pada elaborate. Fase ini dapat dilakukan dengan mengaitkan konsep yang dipelajari dengan konsep yang lain (Eisenkraft, 2003); 7) Evaluate (mengevaluasi), pada tahap evaluasi guru mengevaluasi hasil belajar siswa (Huang et al, 2008).
Aktivitas belajar dalam learning cycle 7E dapat memberi keuntungan kepada siswa diantaranya dapat meningkatkan ketertarikan siswa dalam belajar Learning cycle 7E juga dapat membantu siswa memperoleh pengetahuan baru oleh dirinya sendiri (Polyem et al, 2011). Sanjaya (2010) mengemukakan bahwa pengetahuan yang dikonstruksi sendiri oleh siswa akan menjadi pengetahuan yang bermakna, sedangkan pengetahuan yang hanya diperoleh melalui proses pemberitahuan tidak akan menjadi pengetahuan bermakna. Pengetehuan tersebut hanya untuk diingat sementara setelah itu dilupakan. Aktivitas dalam learning cycle 7E lebih banyak dilakukan oleh siswa sehingga siswa menjadi lebih aktif dalam pembelajaran. Siribunnam dan Tayraukham (2009), menambahkan bahwa setiap fase dalam learning cycle $7 \mathrm{E}$ mendukung siswa untuk mengembangkan kemampuan berpikirnya sehingga hasil belajarnya juga meningkat.

Berdasarkan uraian di atas, rumusan masalah dalam penelitian ini adalah :

Bagaimana kelayakan perangkat pembelajaran berbasis inkuiri dengan model Learning Cycle 7E topik Cahaya yang dikembangkan, meliputI: 1) Bagaimana validitas perangkat yang dikembangkan, terdiri atas : a)Bagaimana kebenaran perangkat pembelajaran yang dikembangkan?; b) Bagaimana tingkat kesulitan perangkat yang dikembangkan?; c) Bagaimana keterbacaan perangkat yang dikembangkan?; 2) Bagaimana efektivitas pembelajaran dengan menggunakan perangkat pembelajaran berbasis inkuiri dengan model learning cycle 7E pada pokok topik cahaya, dilihat dari: a) Bagaimana respon siswa terhadap pembelajaran ?; b) Bagaimana hasil belajar siswa setelah mengikuti kegiatan pembelajaran?; 3) Bagaimana kepraktisan perangkat pembelajaran berbasis inkuiri dengan model Learning Cycle 7E topik Cahaya dilihat dari : a) Bagaimana keterlaksanaan RPP?; b) Bagaimana aktivitas siswa dalam kegiatan belajar mengajar ?; c) Kendalakendala apa yang ditemukan pada saat kegian belajar mengajar? Tujuan penelitian ini adalah: mendeskripsikan kelayakan perangkat pembelajaran berbasis inkuiri dengan model Learning Cycle 7E topik Cahaya yang dikembangkan, meliputi: 1) Mendeskripsikan Validitas Perangkat pembelajaran; terdiri atas: a) Kebenaran perangkat pembelajaran yang dikembangkan; b) Tingkat kesulitan perangkat yang dikembangkan; c) Keterbacaan perangkat yang dikembangkan; 2) Mendeskripsikan efektivitaS pembelajaran dengan menggunakan perangkat pembelajaran berbasis inkuiri dengan model learning cycle 7E pada pokok topik cahaya, dilihat dari: a) Hasil belajar siswa setelah mengikuti kegiatan pembelajaran; b) Respon siswa terhadap pembelajaran; 3) Mendeskripsikan kepraktisan perangkat pembelajaran berbasis inkuiri dengan model Learning Cycle 7E topik 
Cahaya; terdiri atas : a) Keterlaksanaan RPP; b) Aktivitas siswa dalam kegiatan belajar mengajar; c) Kendalakendala yang ditemukan pada proses pembelajaran.

\section{METODE PENELITIAN}

Penelitian ini dilaksanakan di SMPN 1 Tuban pada tanggal 20 Juli 3 Agustus 2013. Subjek penelitian ini adalah: perangkat pembelajaran (silabus, rencana pelaksanaan pembelajaran, lembar kerja siswa, dan lembar penilaian). Sampel penelitian ini adalah siswa kelas VIII semester gasal tahun pelajaran 2013/2014 yaitu sebanyak 3 kelas. Penelitian ini dilaksanakan melalui tiga tahap, yaitu pengembangan perangkat dengan model Kemp, validasi perangkat, dan ujicoba lapangan dengan rancangan one group pretest-posttest design.

Desain ujicoba dirumuskan seperti di bawah ini:

\section{$01 \times 02$}

Keterangan:

$\mathrm{O} 1=\mathrm{Uji}$ awal (pretest), untuk mengetahui penguasaan materi sebelum perlakuan

$\mathrm{O} 2=\mathrm{Uji}$ akhir (posttest), untuk mengetahui penguasaan materi sesudah perlakuan

$\mathrm{X}=$ Perlakuan

Sebelum perlakuan siswa diberikan pretest dan setelah perlakuan diberikan posttest topik cahaya. Teknik yang digunakan untuk mengumpulkan data dalam penelitian ini adalah pemberian angket untuk mengetahui tingkat kesulitan belajar, pengamatan untuk mengetahui keterlaksanaan RPP dan aktivitas siswa dalam pembelajaran, dan teknik tes untuk mengetahui keterbacaan perangkat dan hasil belajar siswa. Ketuntasan hasil belajar siswa meliputi ketuntasan individual,klasikal dihitung berdasarkan kriteria ketuntasan minimum yang ditetapkan di SMPN 1 Tuban, yaitu dikatakan tuntas belajarnya (ketuntasan Individu) jika proporsi jawaban benar siswa $\geq 80 \%$, dan suatu kelas dikatakan tuntas belajarnya (ketuntasan klasikal) jika dalam kelas tersebut terdapat $\geq 85 \%$ siswa yang telah tuntas belajarny, dan ketuntasan tujuan pembelajaran tercapai apabila proporsi jawaban benar $\geq 75 \%$. Adanya peningkatan hasil belajar dapat diketahui melalui analisis indeks gain (N-Gain ). Siswa mengalami peningkatan hasil belajar tinggi apabila $\mathrm{N}$-Gain lebih dari 0,7 , peningkatan hasil belajar sedang ditunjukkan oleh $\mathrm{N}$-Gain antara 0,7 sampai dengan 0,3 , dan peningkatan hasil belajar rendah apabila N-Gain yang diperoleh dibawah 0,3 (Hake,1998).

\section{HASIL DAN PEMBAHASAN}

Validasi perangkat pembelajaran oleh pakar dilakukan untuk mengetahui apakah perangkat tersebut baik atau tidak digunakan dalam proses pembelajaran perengkat pembelajaran yang divalidasi meliputi silabus, RPP, materi ajar, LKS, Lembar Penilaian dan kisi-kisi lembar penilaian. Hasil validasi silabus menunjukkan bahwa silabus yang dikembangkan dalam penelitian ini berkategori baik, dapat digunakan dengan revisi kecil dan reliabilitas instrumen rata-rata $100 \%$. Silabus dikembangkan dengan merujuk pada Silabus yang diterbitkan oleh Badan Standar Nasional Pendidikan (BSNP) tahun 2007 dengan menambahkan beberapa indikator sesuai dengan Kurikulum Tingkat Satuan pendidikan (KTSP) SMP Negeri 1 Tuban. Hasil validasi RPP menunjukkan bahwa pada komponen format diperoleh skor rata-rata 4,25 dengan koefisien Reliabilitas rata-rata 94,5\%, sehingga komponen format RPP termasuk kategori baik . Pada komponen isi diperoleh skor rata-rata 4,5 dengan koefisien reliabilitas rata-rata 96,83\%, sehingga komponen isi RPP termasuk kategori baik, pada komponen bahasadiperoleh skor rata- rata 4,16 dengan koefisien reliabilitas rata-rata $96,83 \%$, hal ini menunjukkan komponen bahasa dalam RPP termasuk dalam kategori baik. Setelah dilakukan revisi sesuai dengan saran-saran validator, maka secara umum RPP yang dikembangkan termasuk dalam kategori baik dan dapat digunakan dalam pembelajaran karena telah memenuhi syarat kevalidan. Hasil validasi LKS menunjukkan pada komponen format diperoleh skor penilaian rata-rata 4,25 dengan koefisien reliabilitas 94,5\%. Komponen Bahasa memperoleh skor rata-rata 4,21 dengan koefisien reliabilitas 95,24 dan pada komponen isis diperoleh skor rata-rata 4,22 dengan koefisien reliabilitas rata-rata 95,11\%. Dari hasil validasi LKS yang meliputi ketiga komponen tersebut menunjukkan bahwa ketiganya termasuk dalam kategori baik. Validasi materi ajar meliputi beberapa komponen. Secara umum komponen bahasa termasuk dalam kategori cukup baik. Adapun pada komponen penyajian yang meliputi teknik penyajian, pendukung materi penyajian dan penyajian pembelajaran secara umum termasuk dalam kategori cukup baik. Setelah dilakukan revisi sesuai dengan saransaran validator, maka secara umum materi ajar yang dikembangkan termasuk dalam kategori baik dan dapat digunakan dalam pembelajaran karena telah memenuhi syarat kevalidan.

Hasil validasi lembar penilaian produk dan proses menunjukkan terdapat beberapa butir soal yang memerlukan perbaikan Pada soal proses, revisi dilakukan pada butir ke 2 dan ke 3 yaitu menyusun redaksi soal dan menata ulang urutan pertanyaan. Lembar penilaian hasil belajar produk, proses dan psikomotor dan lembar penilaian afektif dinyatakan baik dan dapat digunakan dengan revisi kecil . Berdasarkan hasil analisis diperoleh tingkat kesulitan rata-rata untuk materi ajar adalah 9,12\% dan 
tingkat kesulitan rata-rata untuk LKS adalah 8,20\%. Sehingga kedua perangkat tersebut termasuk dalam kategori tingkat kesulitan sangat rendah dan materi mudah difahami oleh siswa. Dengan demikian kedua perangkat tersebut layak dipakai siswa dalam proses pembelajaran. Hasil analisis diperoleh keterbacaan ratarata untuk materi ajar adalah $73,75 \%$ dan keterbacaan rata-rata untuk LKS adalah 77,08\%. Sehingga kedua perangkat tersebut termasuk dalam kategori tingkat keterbacaan tinggi dan mudah difahami oleh siswa.

Untuk mengetahui efektivitas penerapan perangkat pembelajaran berbasis inkuiri dengan model Learning Cycle 7E, maka dilakukan pengamatan beberapa aspek yaitu penelitian terhadap peningkatan hasil belajar siswa dan respon siswa terhadap pembelajaran. Hasil belajar produk, proses dan psikomotor pretest (U1)menunjukkan semua siswa tidak ada yang mencapai ketuntasan individual $1 \geq 80 \%$, sehingga secara klasikal juga tidak mencapai ketuntasan.Hal ini terjadi karena U1 dilaksanakan sebelum siswa mendapatkan materi yang diujikan sehingga semua siswa belum memiliki pemahaman yang baik tentang materi tersebut. Setelah seluruh proses pembelajaran berbasis inkuiri dengan model Learning Cycle 7E selama tiga kali pertemuan diselesaikan, dilakukan post-test(U2) dengan butir soal yang sama dengan U1. Hasil post-test produk dan proses kelas VIII-C, 24 siswa (88,9\%) telah melampaui KKM, dan dinyatakan tuntas secara individual, namun terdapat 3 siswa tidak tuntas. Kelas VIII-D 24 siswa telah melampaui KKM dan dinyatakan tuntas secara individual, terdapat 3 siswa yang tidak tuntas. Hasil post test proses menunjukkan 25 siswa dinyatakan tuntas secara individual dan 2 siswa tidak tuntas. Hasil post-test produk dan proses kelas VIII-C 24 siswa (88,9\%) telah melampaui KKM, dan dinyatakan tuntas secara individual, namun terdapat 3 siswa tidak tuntas. Beberapa siswa belum dapat mencapai ketuntasan individual terjadi karena ada beberapa konsep yang belum difahami siswa dengan baik. Faktor lain yang menyebabkan siswa tersebut tidak tuntas dalam belajar adalah persiapan siswa menghadapi ujian kurang (siswa tidak belajar sungguh-sunggguh). Hasil belajar psikomotor pada masing-masing kelas menunjukkan semua siswa dapat mencapai ketuntasan individual. Secara klasikal hasil belajar produk, proses dan psikomotor semua kelas dinyatakan tuntas karena telah mencapai ketuntasan individual diatas $85 \%$. Hal tersebut menunjukkan bahwa hasil belajar yang dicapai pada ketiga kelas menunjukkan hasil yang konsisten.

Hasil perhitungan $\mathrm{N}$-gain pada hasil belajar produk, proses dan psikomotor pada kelas VII-C, VIII-D dan VIII-E. Berdasarkan tabel tersebut diperoleh N-gain rata-rata untuk hasil belajar produk, proses dan psikomotor kelas VIII-C adalah $0,84,0,88$ dan 0,87 , pada kelas VIII-D diperoleh N-Gain rata-rata hasil belajar produk, proses, dan psikomotor berturut-turut adalah 0,82 , 0,88 dan 0,86 , pada kelas VIII-E diperoleh N-Gain rata-rata hasil belajar produk. proses dan psikomotor berturut-turut adalah $0,83,0,88$ dan 0,84 . N- gain yang dihasilkan masing-masing kelas lebih besar dari 0,70 artinya ketiga kelas mengalami peningkatan hasil belajar dengan kategori yang sama, yaitu tinggi, sehingga peningkatan hasil belajar pada ketiga kelas sampel adalah konsisten. Hal ini diperkuat dengan perhitungan statistik Analysis of Varians yang menunjukkan tidak ada perbedaan yang signifikan antara ketiga kelas terhadap peningkatan hasil belajar, artinya pembelajaran berbasis inkuiri dengan model Learning Cycle 7E berpengaruh secara signifikan terhadap pembelajaran pada kelas VIII-C, VIII-D dan VIII-E. Setelah siswa mengikuti proses pembelajaran berbasis inkuiri dengan model Learning Cycle 7E topik cahaya selama tiga kali pertemuan dan dilakukan U2 diperoleh semua tujuan pembelajaran produk pada kelas VIII-C seluruhnya tuntas. sesuai dengan KTSP SMPN 1 Tuban, ketuntasan tujuan pembelajaran tercapai jika semua proporsi jawaban benar $\geq 75 \%$. Pada kelas VIII-D terdapat dua tujuan pembelajaran yang tidak tuntas yaitu TP ke 18 dan 19, pada kelas VIII-E terdapat satu tujuan pembelajaran yang tidak tuntas yaitu TP ke 17, Hal terebut terjadi karena butir soal pada TP tersebut memiliki tingkat kesulitan yang lebih tinggi dibandingkan yang lain, (siswa diminta untuk menganalisis gambar dan perhitungan matematis), dalam proses pembelajaran waktu yang digunakan untuk membahas soal kurang, sehingga jika persiapan belajar siswa di rumah (untuk latihan soal) kurang, maka siswa akan mengalami kesulitan saat ujian. Tujuan pembelajaran proses dan psikomotor pada ketiga kelas seluruhnya mencapai ketuntasan. Hal ini menunjukkan ketuntasan tujuan pembelajaran yang dicapai ketiga kelas adalah konsisten. Analisis Hasil Belajar siswa juga memaparkan bahwa semua butir soal produk, proses dan psikomotor memiliki sensitivitas yang tinggi. Hal ini menunjukkan bahwa semua butir soal dapat digunakan untuk mengukur efek pembelajaran. Nilai sensitivitas butir soal yang semakin besar menunjukkan bahwa kepekaan butir soal terhadap efek-efek pembelajaran juga semakin besar (Kardi, 2002). Suatu butir soal dikatakan peka terhadap efek-efek pembelajaran apabila sensitivitas butir soal $\geq 0,3$ (Aiken, 1997). Hasil belajar afektif siswa, dari tabel tersebut menunjukkan adanya perkembangan sikap yang konsisten pada ketiga kelas. Setelah mengikuti proses pembelajaran berbasis inkuiri dengan model Learning Cycle 7E telah tercipta budaya dan kebiasan untuk berperilaku tanggung jawab serta telah muncul ketrampilan sosial pada diri siswa untuk berani mengemukakan ide/pendapat serta menjadi pendengar yang 
baik. Hal ini ditunjukkan dari hasil pengamatan bahwa jumlah siswa yang mencapai hasil belajar afektif sangat baik dan memuaskan rata-rata melebihi 70\%. Respon siswa terhadap model dan perangkat pembelajaran. Hasil Penelitian menunjukkan bahwa respon siswa dari ketiga kelas adalah konsisten, yang ditunujukkan dengan persentase rata-rata respon siswa terhadap pembelajaran pada masing-masing kelas menunjukkan persentase respon yang tidak berbeda jauh.Berdasarkan hasil angket diperoleh $98 \%$ siswa senang terhadap topik fisika yang dipelajari, $87,89 \%$ siswa menyatakan bahwa perangkat pembelajaran tersebut masih baru bagi mereka terutama model Learning Cycle, bahkan $100 \%$ siswa menyatakan berminat untuk mengikuti pembelajaran fisika untuk topik-topik selanjutnya dengan menggunakan perangkat tersebut. Pendapat siswa terhadap buku/materi ajar mengenai kejelasan bahasa 91,67\% menyatakan jelas, $83,67 \%$ menyatakan penampilan dan isi materi ajar menarik, 81,33\% menyatakan gambar-gambarnya menarik. Hal ini menunjukkan bahwa buku/materi ajar tersebut dapat diterima oleh siswa dan dapat digunakan sebagai salah satu perangkat pembelajaran.

Untuk mengetahui kepraktisan pembelajaran pada penerapan perangkat pembelajaran berbasis inkuiri dengan model Learning Cycle 7E, dilakukan pengamatan terhadap keterlaksanaan RPP, aktivitas siswa selama pembelajaran dan kendala-kendala yang dihadapi pada saat pembelajaran berlangsung. Hasil pengamatan menunujukkan bahwa seluruh aspek yaitu keterlaksanaan sintaks pembelajaran berbasis inkuiri dengan model Learning Cycle 7E melalui fase-fasenya yaitu Elicit, Engage, Explore, Explain, Elaborate, Extend, dan Evaluate, pada pertemuan pertama sampai dengan pertemuan ketiga diperoleh rerata setiap fase pembelajaran terlaksana dengan kategori baik, aspek suasana kelas baik dan pengelolaan waktu cukup baik.

Hasil pengamatan ini menunjukkan bahwa rata-rata keseluruhan keterlaksanaan RPP dinilai oleh pengamat pada ketiga kelas adalah konsisten karena rata-rata keseluruhan keterlaksanaan RPP pada ketiga kelas termasuk pada kategori yang sama, yaitu kategori baik . Rerata koefisien reliabilitas dari keseluruhan kelas adalah 97,67\%. Hal ini sesuai dengan ketentuan yang ditetapkan oleh Borich (1994), suatu instrumen dikatakan reliabel jika nilai reliabilitas instrumen $\geq 0,75$. aktivitas siswa yang menonjol pada ketiga kelas adalah aktivitas yang sama, tiga persentase terbesar pertama berturut-turut adalah aktivitas siswa melakukan percobaan/ pengamatan 18,44\%, menganalisis hasil percobaan $16,48 \%$, diskusi / tanya jawab $15,73 \%$. Aktivitas siswa dalam penelitian ini menggambarkan bahwa dalam pembelajaran dengan model Learning Cycle 7E lebih berorientasi pembelajaran berpusat pada siswa dan siswa saling berinteraksi satu sama lain. Hal ini sesuai dengan pernyataan Fosnot dalam Suparno (1997:73), bahwa prinsip konstruktivisme lebih menekankan keaktifan siswa baik dalam belajar sendiri, bersama maupun kelompok. Dari pengamatan aktivitas siswa terlihat bahwa proses inkuiri (antara lain melakukan percobaan/pengamatan, menganali sis hasil percobaan) sangat menonjol dalam kegiatan pembelajaran. Hal tersebut sesuai dengan pengertian inkuiri yaitu suatu penyelidikan proses bertanya dan mencari tahu jawaban terhadap pertanyaan ilmiah yang diajukan (Eggen \& Kauchack 1996). Keberhasilan pendekatan inkuiri ditentukan oleh keseluruhan aspek pengajaran di kelas, proses keterbukaan dan peran aktif siswa. (Arends, 1994: 373).

Kendala utama yang diitemui selama pembelajaran pada ketiga kelas tidak jauh berbeda antara kelas yang satu dengan kelas yang lain, yaitu proses pembelajaran belum dapat selesai sesuai waktu yang dialokasikan. Hal ini disebabkan siswa belum terbiasa dengan pembelajaran berbasis inkuiri dengan model Learning Cycle 7E, pembelajaran siswa masih ramai, Siswa belum percaya diri dalam kegiatan presentasi, masih enggan untuk bertanya dan menyampaikan pendapat. Masih terdapat siswa yang kurang aktif dalam kerja kelompok. Peralatan percobaan (terutama cermin dan laser pointer) dipakai mainan oleh beberapa siswa. Secara umum solusi yang diberikan dapat mengatasi kendala-kendala tersebut sehingga tidak menjadikan pembelajaran mengalami hambatan yang berarti. Kesungguhan guru dalam mengorganisir waktu dan membimbing siswa, serta antusias siswa untuk terlibat dalam pembelajaran diperlukan agar proses pembelajaran dapat berjalan sesuai yang diharapkan.

\section{KESIMPULAN DAN SARAN}

Berdasarkan hasil temuan penelitian, perangkat pembelajaran berbasis inkuiri dengan model Learning Cycle 7E topik Cahaya yang telah dikembangkan dengan model Kemp 1) memenuhi unsur kevalidan; a) Hasil validasi perangkat menunjukkan perangkat pembelajaran yang dikembangkan berkategori baik dan dapat diterapkan dalam kegiatan belajar mengajar; b) Tingkat kesulitan perangkat yang dikembangkan rendah dan mudah difahami siswa; c) Keterbacaan perangkat tinggi dan materi mudah difahami; 2) memenuhi unsur efektifvitas a) Hasil belajar kognitif produk, proses, psikomotor, dan afektif menunjukkan peningkatan dengan kategori tinggi. b) Siswa memberikan respon positif terhadap perangkat pembelajaran yang dikembangkan. 3) memenuhi unsur kepraktisan; a) keterlaksanaan RPP dalam kategori baik; b) Aktivitas siswa yang memiliki peresentase tiga terbesar adalah menganalisis hasil percobaan, melakukan percobaan/ pengamatan, dan diskusi atau tanya jawab; 
sehingga dapat disimpulkan bahwa Perangkat Pembelajaran berbasis inkuiri dengan model Learning Cycle 7E topik Cahaya layak diimplementasikan dalam pembelajaran.

Berdasarkan simpulan yang telah diuraikan di atas, peneliti dapat memberikan beberapa saran sebagai berikut :

1. Persiapan dan pengelolaan waktu perlu mendapat perhatian, karena penerapan perangkat pembelajaran berbasis inkuiri dengan model 7E membutuhkan waktu yang lebih lama.

2. Perangkat pembelajaran yang telah dikembangkan perlu diperbaiki dan diujicobakan lebih luas sehingga diperoleh hasil yang dapat diandalkan.

3. Pembelajaran berbasis inkuiri dengan model Learning Cycle 7E merupakan salah satu model pembelajaran yang dapat dijadikan alternatif untuk meningkatkan hasil belajar, sehingga perangkat ini perlu dikembangkan dan diimplementasikan pada topik lain yang sesuai.

\section{DAFTAR PUSTAKA}

Arends, Richard .I. 1997. Classroom Instruction and Management. New York : McGraw-Hill Company. Arikunto, Suharsimi. 2010. Prosedur Penelitian, Suatu Pendekatan Praktek. Edisi revisi. Jakarta: Rineka Cipta.

Borich, G.D. 1994. Observation Skill for Effective Teaching. Second Edition. New York: McMillan Publishing Company.

Eggen, P.D., dan Kauchak, D.P. 1993. Strategies for Teachers Teaching Content and Thinking Skill. Third Edition. Boston: Allyn and Bacon.

Eisenkraft, Arthur., 2003, Expanding the 5E Model, A Journal for High School Science Educators Published by The National Science Teachers Association The Science Teacher Vol. 70, No.6.

Hake, R. R. 1998. Analyzing Change Gain Skores [online].

Tersedia: http://www.physics.indiana.edu/ sdi/AnalyzingCha nge-Gain.pdf.

Huang, K.J., Liu, T.C., Graf, S., and Lin, Y.C., 2008, Embedding Mobile Technology to Outdoor Natural Science Learning Based on The 7E Learning Cycle. In J. Luca \& E, Weippl (Eds.), Proceedings of World Conference on Educational Multimedia, Hypermedia and Telecommunications 2008 (pp. 2082-2086). Chesapeake, VA: AACE.

Kardi, S. 2002. Mengembangkan Tes Hasil Belajar. Diktat Matakuliah PBP. Surabaya: Pendidikan Sains PPs. Universitas Negeri Surabaya. Polyem, T., Nuangchalerm, P., and Wongchantra, P., 2011, Learning Achievement, Science Process Skills, and
Moral Reasoning of Ninth Grade Students Learned by 7E Learning Cycle and Socioscientific Issue-based Learning, Australian Journal of Basic and Applied Sciences 5(10): 257-564, ISSN 1991-8178.

Sanjaya, Wina., 2010, Strategi Pembelajaran Berorientasi Standar Proses Pendidikan, Kencana, Jakarta. Siribunnam, R., and Tayraukham, S., 2009, Effect of 7-E, KWL and Conventional on Analitycal Thinking, Learning Acievement and Attitudes toward Chemistry Learning, Journal of Social Sciences 5(4):279-282. 